\title{
MASTER
}

\section{Transient Diffusion Through a Spherical Shell into Its Finite Spherical Core}

\author{
M. Reeves \\ J. S. Tolliver
}


CBRL/CSD/T -60

Contract No. H-7405 eng 26

COMPOTER SCIERCES DIVISICH

TRANSIENT LIFPUSION THECOGH S SPHERICAL SHEII

INIC ITS FINITE SPHERICAI COEE

9. Beeves* and-J. S. Tolliver

Conputer Sciences Divisicn

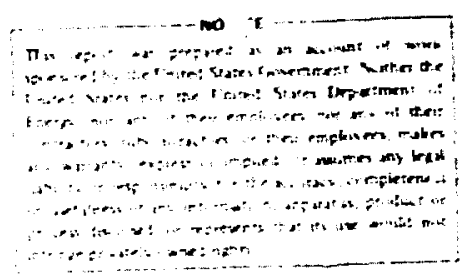

Spcnsor: C. S. Mcrgan

Criginator: J. S. Tcliiver

* Hoy at INTERA Enviconmental Consultants Inc., Houstor. IX.

Date Publisbed - August 1979

NOTICE This docisment contains intormation of a prei.minary nature

If is subject to pev sion ar coerection and therefore does not reprssent a

linal report

UHION CARBICE CCRPORATION, NOCIEAR DIVISICN

cperating the

Cak Ridge Gaseous Diffusion Plant Oak Iidge National Laboratory Cak Eidge $Y-12$ Plat

for the

DEPABTEENT OF ENEGGY 


\section{consers}

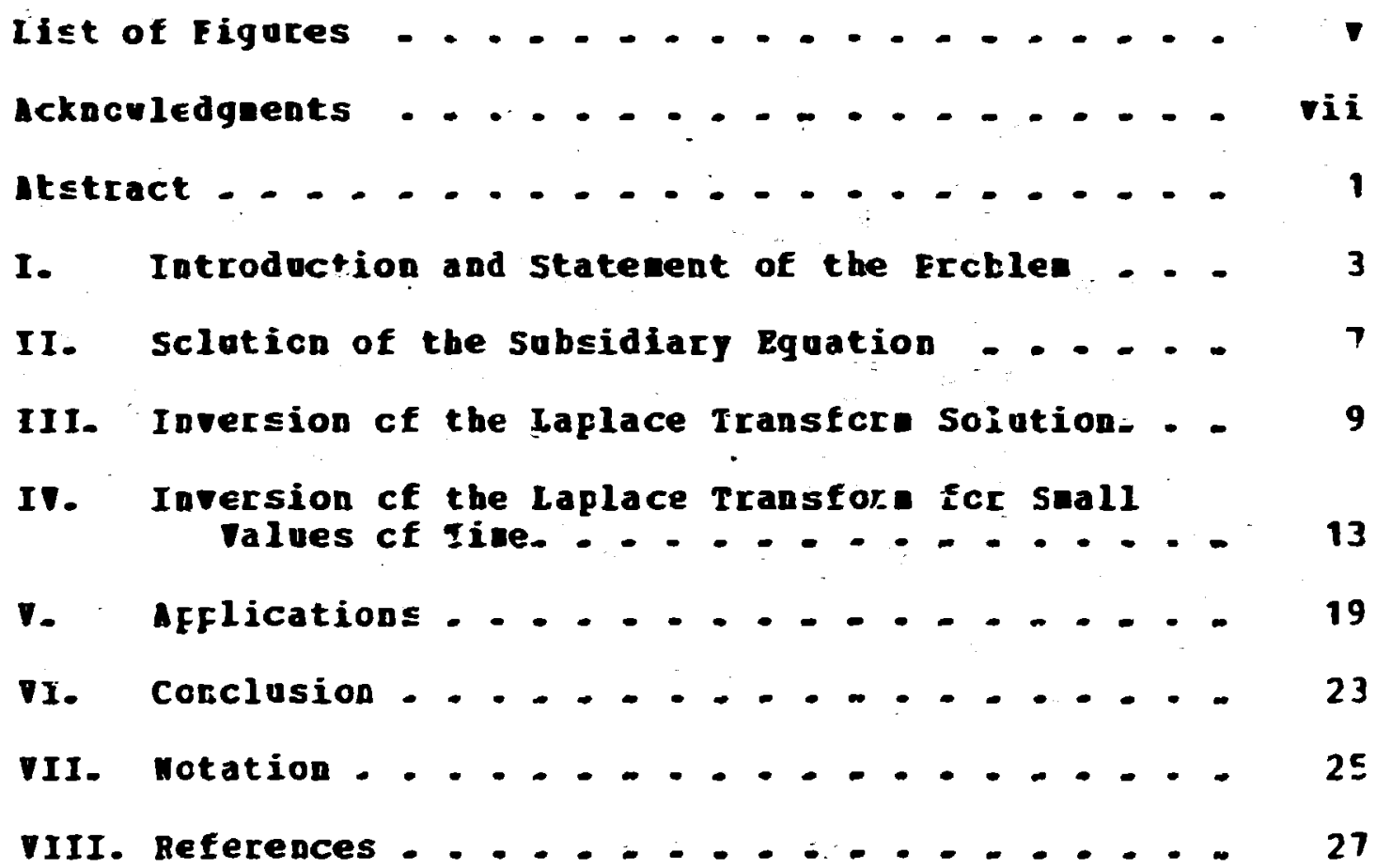


Eigure

1. Cross-sectional vieu of the spherical shell and its inner core together with gecnetrical and aterial paraneters.

i- Cceplez plane of the Iaplace-transformation paraneter :- Iocations cf sone of the foles in guantity $\overline{\mathbf{Q}}$ are indicated. . . . . . . . . . 10

3. I wo sanfle curves shouing the behavior of the theoretical gas oftake as a function of tive for two different sets of faraneters. - . - 20

4. Experimentul data and the tbeoretical fit for the heliug optake by BIGB fuel-farticle tatch $0 F 2261 / 7 T$ at $E 50^{\circ} \mathrm{C}$. The tbeoretical fit yields $D=4.055 \times 10^{-12}{ }^{2} / s, D=0.0471$. and $s=0.1948$ 
vii

ACKBCALEGEEATS

Funding for this project was provided by the Gas cooled Reactor Base Technology Program. The a othors would like to thank D. R-Eatherly. C. S. Longan, and G. I. Powell for their helpful consents and c. R. Cook and P. A. DeCoy of the Computing Applications Department secretarial staff for preparing this report for publication. 


\title{
TEASSIENT DIFPOSIOA TBROUGH S SFBERICAL SBEII IMTO IIS PINITE SHERICAI COAE \\ t. Reeves and J. S. Tolliver
}

\begin{abstract}
AESTRACT
The froblea cf the dif:usion of gas through a spherical shell into its spherical core is sclred by using the Laplace transform technigue. The transfcrned scluticn is cbtained and then inverted to the corresponding soluticn in real space. This real sface soluticn is slovly converging for srall tines. Therefore, an al ternute expression is obtained that is arpropriate and more rapidy convergent for sull tives. ns an exanple, the first scluticn is used to calculate the thecretical gas content of the core of Bigh-Terferatare Gas-Cooled Beactor (BTGR) hiso-coated fuel farticles fron fuel-farticle batch cr2261/月I after $850^{\circ} \mathrm{C}$ anneals in beliun.
\end{abstract}




\section{IHTRODUCTION AND STATENE:T OF THE PROSLER.}

High-Tenperature Gas-Cooled Reactor (HTGF) biso-coatex. Euel particles consist of. an inner core of $\mathrm{Th}_{2} \mathrm{O}_{2}$ fuel which is coated with a layer of porous carbol and a layer of dense carbor.. The porous layer. called the buffer, serves as a reservoir for fission gasses while the dense outer layer serves as a pressure vessel. The high temperature inert gas peraeability of the fuel particles is of interest and has been studied experimentally at nak Ricge National Laboratory and the oak Ridge $Y-12$ plant iy sorgan and powell (1977) ard by norgan. Eatherly, and Powell (1977). This report conziders the theoretical aspects of the proulem by examining the diffusion of gas through a dense spherical shell into a low density spherical core. Nuclear Technology. Volume 35. is a special issue related to HTG fuel particles ard may be referred to for more detailed information about the fuel particles.

Pigure 1 shows a composite sphers submerǵged in a gas of constant concentration $c_{0}$. The geonetry is characterized both by the raaii $a$ and $b$ and by the porosities $n$ and $s$. It is assumed that the pore dimensions of the inner region are sufficiently large compared to the wean free path of the gas that mass transport occurs essentially instantaneouslyn si:ch an assumption allows one to concentrate on the shell, which, with diffusivity $D$, is much wore resistant to penetration by the gas. 
ORNL-DWG 76-20680

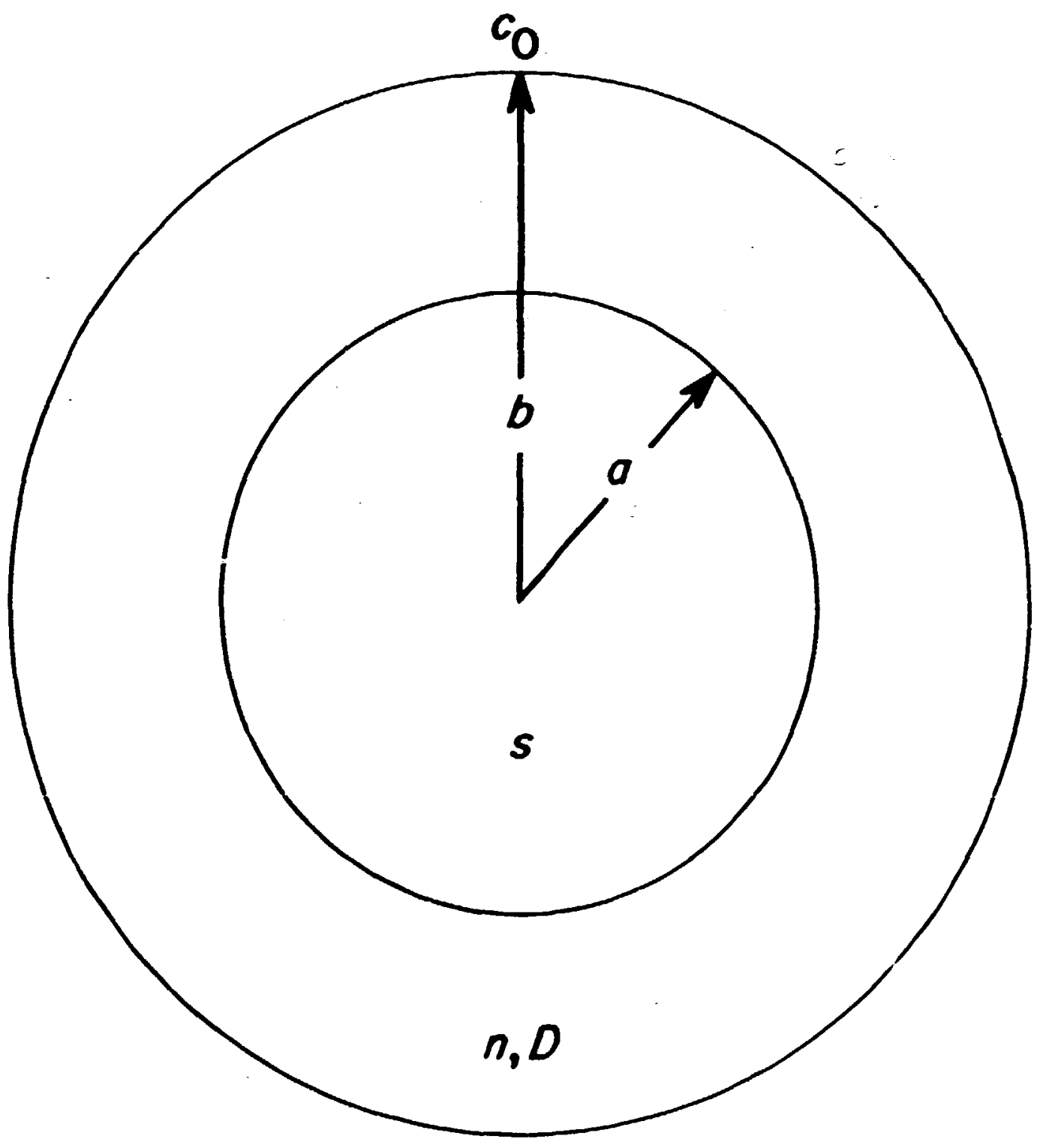

P1g. 1. Crose-sectional viev of the spherical sbell and its inner core togetber vith gecretrical and waterial faraveters. 
Diffusicn within this shell is characterized by the equation

$$
\frac{\partial c}{\partial t}=\frac{D}{r} \frac{\partial^{2}}{\partial r^{2}}(r c)
$$

where $c$ is the ccacentration, $r$ is the radial distance. and $t$ is tbe tine. The initial conditicn is

$$
\operatorname{cir}, t=j)=0
$$

and the two bcundary conditions are

$$
c(r=b, t)=n c_{0}
$$

a.d

$$
\left[q \frac{\partial C}{\partial t}-D \frac{\partial C}{\partial r}\right]_{r=a}=0
$$

vbere

$$
q=\frac{s a}{3 n}
$$


Rhysically zg. (2c) is tased upon the characteristics of the inner core. Jue to the assunticn of instantaneous diffusion, the concentrationat the inner core is independent of positicn ana is Frcectional to the shell concentration evaluated at the interface. Because of the finiteness of tbe inner core, the rate of change of the ccncentration is then related to the interface flox, -rjc/or. The constant cf froporticnality 9 is related to the porosities and the radius cf the irner core, as shown in Rq(3).

Hathenatically the internal boundary ccudition cxfressed in Eg- (zc) can be a source cf considerable difficulty- The fredicament here arises frod the fact tbat eigenfunctions ccnstructed to satisfy this bcundary condition and the exterral toundary condition [Eg. (2b)] aro not crthcgonal. Thus it is grite difficult tc incorfcrate the initial ccndition [Rg. (2a)] into this fordulaticn. Carslaw and Jaeger [1959] sention this difficulty in the fcotnote cn fage 240. The solution, hoyever, is easily cbtained using the Laflace transformatics:

$$
\ddot{c}(i)=L[c(t)]=\int_{n}^{x} e^{-i t} c(t) d t
$$

where is couplex. 


\section{SOIOTICA OP IHE SUESIJIAEY ECOATION}

By applying the Laflace transformation to Egs. (1) and (2). coe ortzins the subsidiary equation

$$
\frac{D}{r} \frac{\bar{j}^{2}}{\partial r^{2}}(\overline{r c})=\bar{c}
$$

vith

$$
\bar{c}(\bar{r}=b)=n c_{\dot{s}} / \vec{s}
$$

and

$$
\left[r \bar{c}-D \frac{\bar{C}}{\bar{c}}\right]_{r=d}=0 .
$$

$$
\begin{gathered}
\text { Integration cf Eq- (5) yields an ejuaticn of the for } \\
r \bar{c}=A \operatorname{sirh}(k r)+B \cosh (k r)
\end{gathered}
$$

vbere

$$
k=\sqrt{i} / 0
$$

Ibe boundary conditicns cf Eq. (6) pernit deternination of constants and $E$ so that the solutior cf the subsidiary equatior ay ke uritten

$$
r \bar{c}=\text { bnc }_{:} \bar{Q}
$$


vtere

$$
\eta=1 f(k,:)
$$

(st)

and

$$
\left.f(k, \ldots)=\left(k q_{i}+1\right) \sin h ! k \ldots\right)+k a \cosh (k)
$$

Cuantities: and: aro siople combinations cf the radii:

$$
\therefore=r-a \text { and }:=b-a
$$


III. INVERSION OF THE LAPLACE TRANGOKG SOLOTICA

Here the inverse Laflace transfora cf $\mathrm{Eg}$ - (9) is desired. Isclating the defendence on, and $t$ in Eg. (9a). one cttains

$$
r c(t)=i^{-3}[r \vec{r}(\cdot)]=b_{0} Q(t)
$$

and frce the inversicn theorea

$$
Q(t)=L^{-1}[\overline{\bar{T}}(\lambda)]=\frac{1}{2 \pi i} \int_{i-i \infty}^{i+i x} e^{i t} \bar{Q}(\lambda ; d \lambda .
$$

Faraseter i, a real guantity, is so chosen that all singularities lie tc the ieft cf the line $\left(i-i \cdots, y+i^{\prime}\right)$ in the corflex flane (see Fig. 2).

The integral of Eg. (11b) is wost easily evaluated by podifying the fath of integration. Since $\overline{\mathrm{c}}$ may be shcun to be a single-valued furction of; the closed contour $\Gamma$ (see Pig. 2) ay te csed. Purther, since the infinite senicircular path within "contributes nothing, cne way wite $\mathrm{gg}$. (11b) as follows:

$$
Q(t)=\frac{1}{2 \pi i} \int_{! !} e^{\lambda t} \bar{Q}(\lambda) d \lambda
$$

Ibe corflex integral is therefore transfcrmed into a form suitable for application cf the Cauchy Residue Theores, yielding

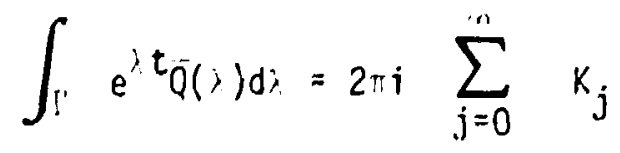




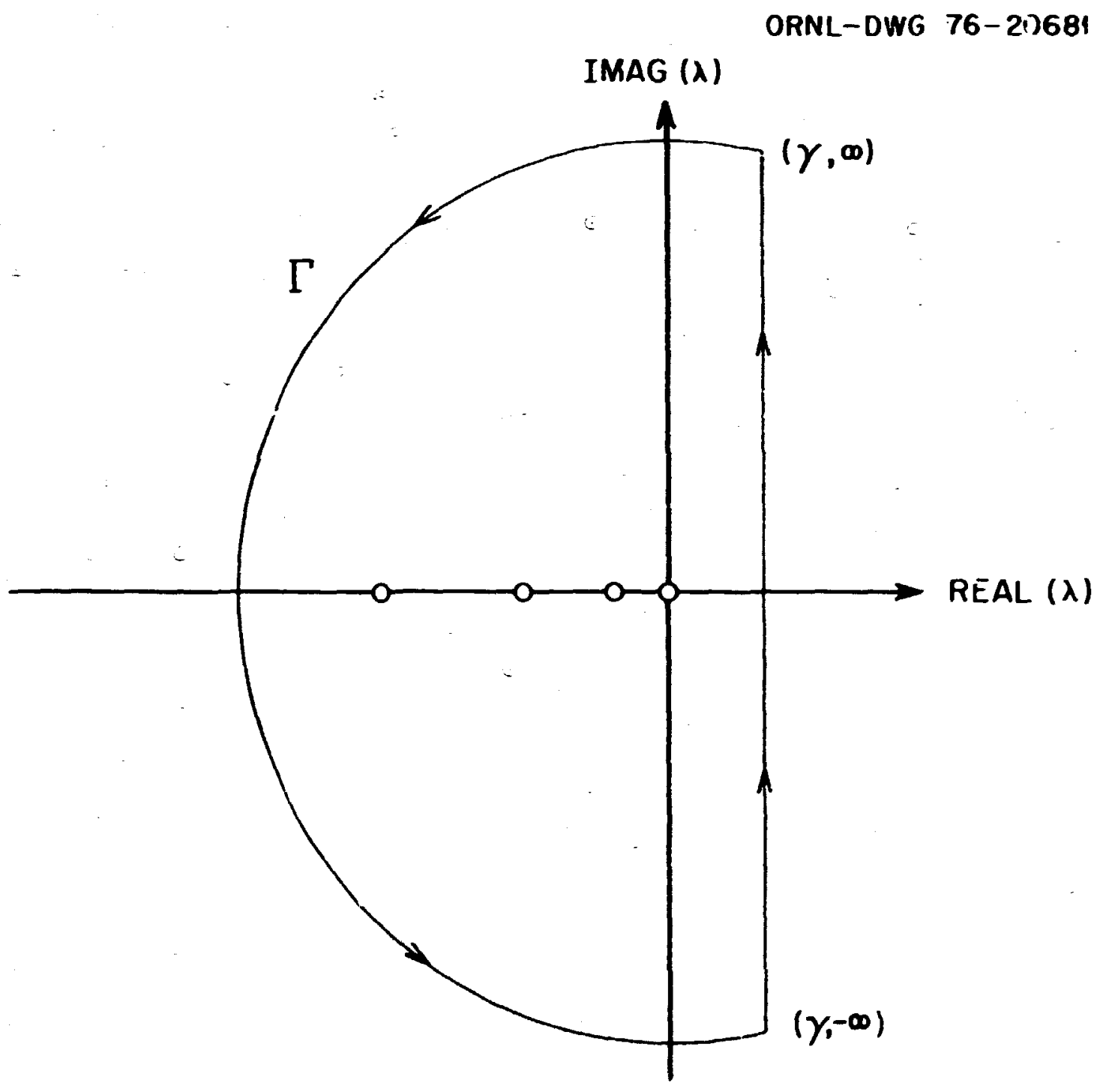

Fig. Zu ccuflex flane of the laplace-transformation paraueter
locaticns of scre cf the fcles in guantity are indicated. 
Where the $x_{j}$ 's are the residues cf the integrand evaluated at the foles enclosed withial contcor :-

The lccation of the fcles ay be deternined by inspection of the dercinatcr of $Q$ in $\mathrm{Rq}$ - (9t)- They are confined tc the ncrecsitive real axis (see fig. 2) as follows:

$$
\because=0 \text { and } i_{j}=-0_{i}{ }^{2}, j=1.2, \ldots
$$

ubere tbe ${ }^{\prime} j=$ are the pcsitive roots cf the transcrndental eguation

$$
\tan \text { si }=\frac{x a}{q a-1}
$$

Besidues of these foles are given by the exfressions

$$
K_{r}=\frac{r}{b}
$$

and

$$
k_{j}=\left[e^{i t_{f}(k, \ldots) / ; \frac{d}{d ;} f(k, \ldots)}\right]_{;=0 ;, j}, j=1,2 \ldots
$$

The desired solution is obtained ky combining Egs. (9). (11), (12), (13), and (15). It is

$$
\left.r c=b n c,\left[\frac{r}{b} \quad \sum_{j=1}^{n} g i{ }_{j}, \ldots\right) e^{0 r_{j}^{j} t}\right]
$$


vtere

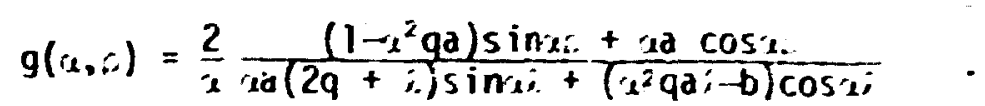

Ey letting a and $t$ apfroach inficity in such a naner that their difference \% renains finite, it ray be easily shown that Eq. (16) reduces to the soluticn used by Jenkins, et al. [1969] for a region tounded by parallel planes. Absolute convergence, and hence ccovergence, way be established for Eg. (16a) ty using a

= sinfle ratio test, except for the case $t=0$. There the ratio test fails, and such convergence ust be established by showing that the Cauchy integral exists. at small tines, howerer, ccnrergence raj be gite slow. and a different exfression is desirable. 


\section{IBVERSIOY DP TBE LAFLACE TEABSFCRT}

\section{FUR SHALL VALOES OP TIUE}

Fcr snal: tines cne takes advantage of the sensitivity of $Q$ tc large: and $k$ values, a fact which is apparent fron the Inversion Theoren. Eg- (11), and táe definiticn of $k$, Eq. (8)The idea is tc expand $\bar{c}$ in tars of negative exponentials and inverse fovers of $k$. Ihis frocedure is the sane as that used by Carslat and Jaeger [1959] (see PF- 330-31, for Example).

osing the definitions of the hyperbolic functions in terns of exfonentials, guantity $\overline{\mathrm{C}}$ of $\mathrm{E}$. (9b), takes the forn

$$
\bar{Q}=\frac{1 \mathrm{e}^{-k ! i-c)}-i \mathrm{e}^{-k(i+r)}}{1-\sigma \mathrm{e}^{-2 k}}
$$

BerE

$$
\therefore=\frac{d-x+x^{2}}{d+x+x^{2}}
$$

wtere

$$
d=q / a=\frac{s}{3 n}
$$

frcu Eg. (3) and

$$
x=1 / k a
$$

Exfanding the dencaibator of Eg. (17) as

$$
\left.(1) e^{-2 k \%}\right)^{-1}=\sum_{m=0}^{m} e^{m} e^{-2 m k 2}
$$


and outiflying by the nueratcr, one has

$$
\bar{Q}=\frac{1}{h} \sum_{m=0}^{\infty} i^{m} \mathrm{e}^{-k[(2 m+1) ;-\infty]} \ldots \sum^{m+1} \mathrm{e}^{-k[(2 m+1) ;+z]} !
$$

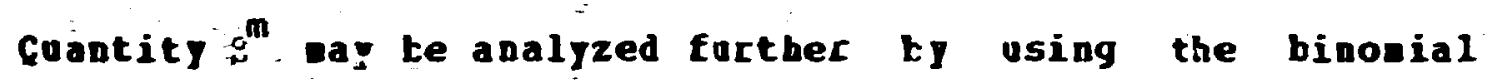
Exfarsicue

$$
(i, y+y)^{-m}=\sum_{i=0}^{\infty}(-1)^{j}\left(\begin{array}{c}
m+i-1 \\
i
\end{array}\right)=-(m+i)_{y} i
$$

and

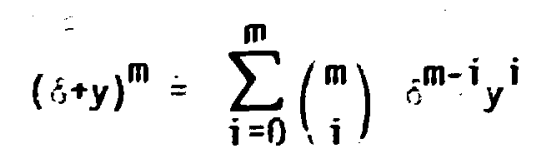

in ubich

$$
\left(\begin{array}{c}
m \\
i
\end{array}\right)=\frac{m !}{i !(m-i) !}
$$

is the usual binosial coefficient. In the frocess cf analyzing 2g. (18). variable $Y$ of $8 g$. (23) is get egual to $x \cdot x^{2}$. $-I+x^{2}, x$, and $-x$, and paraneter $\delta$ asfunes the values $d$ and 0.165\% 
Ifter considerable asout of algetra, one ottains the desired expressicn fcr $:^{\mathrm{m}}$, radel

$$
E^{m}=\sum_{n=0}^{x} E_{n m^{x^{n}}}
$$

vbere

$$
\begin{aligned}
B_{m w} & =\sum_{i=0}^{i} \sum_{j=0}^{j} \sum_{p=p}^{j}(-1)^{w-j}\left(\begin{array}{c}
m+i-i-j-1 \\
m-1
\end{array}\right) \\
& -\left(\begin{array}{c}
w-i-j \\
j
\end{array}\right)\left(\begin{array}{c}
m \\
i-p
\end{array}\right)\left(\begin{array}{c}
i-p \\
p
\end{array}\right) d^{-(w-p-j)}
\end{aligned}
$$

The sonation livits are given by

$$
\begin{aligned}
& I_{u}=\min (w, 2 \pi) \\
& J_{u}=(w-i) / 2 \\
& P_{i}=\max (0, i-m) \\
& P_{u}=i / 2,
\end{aligned}
$$

ECI $=0, E g$. (25a) yields $B_{\text {ow }}=\delta_{\text {ow }}$ where $\delta_{\text {ow }}$ is the Rronecker deIta.

coskining egs. (20), (22), and (24), cne obtains

$$
\bar{Q}=\sum_{m, w=0}^{\infty}\left[B_{m w} \bar{R}_{m w}(-6)-B_{m+1, w} \bar{R}_{m w}(0)\right]
$$


is uhich

$$
\bar{R}_{m i d}(c)=\frac{1}{i} \frac{1}{(k a)^{5}} e^{-k_{s_{m}}(\omega)}
$$

and

$$
\omega_{m}(p)=(2 m+1) s+\cdots
$$

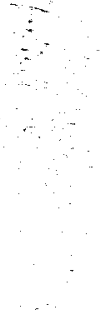

Taxiag hote of the aefiateion of

Taking note cf the definition of $\mathrm{k}$ in Eg. (8). cne may urite

$$
\bar{R}_{m w}(n)=(\sqrt{0} / a)^{w} \frac{1}{\lambda^{1+5 / 2}} e^{-k_{i \omega}}
$$

The ipverse laplace transfcri of $\overline{\mathrm{B}}$ nay be obtained frce tables. (See, for eranfle, Ippendix in Carslau and Jaeger [ 1959]-) The result is

$$
R_{m m}(\rho)=\left(\frac{2 \sqrt{D t}}{a}\right)^{w} i w_{e r f c} \frac{s_{m}(\rho)}{2 \cdot \overline{D t}}
$$

where $i^{W}$ erfc(x) represents the $y$-tin integral of the corpleventary error function. (see, for exanple, Appendix II of carslaw and Jaeger [1959]-)

Ey analogy with egs. (26) and ith the aid of Eg. (30), guantity $Q$ way be written as

$$
Q=\sum_{m, w=0}^{\infty}\left(\frac{2 \sqrt{D t}}{a}\right)^{w}\left[B_{m, t} i^{w} \operatorname{erfc} \frac{(\omega)(-o)}{2 \sqrt{D t}}-B_{m+1, w} i^{w} \operatorname{erfc} \frac{(s) m^{(n)}}{2 \sqrt{D t}}\right] .
$$


According to Eg. (11a). the desired solution is thus $=$

$$
r c=\text { bnc }_{0} Q
$$

On the surface it apfears that Eg- (31) recorers the initial conditicn. Eg. (2a). since at $t=0$ the complerentary error functions egual gerc. It also seens reasonable that Eg. (31a) ccnterges whenever $t \leq I$. where $T$ is a radius of convergence yet tc te deternined. Ic establish these tuc points rigorously. howerer. is quite difficelt and has nct been done to date. The majcr frotlea cones fron the coefficient $B_{\text {mo }}$ defined by Egs. (iE). Dhenerer indices and/cr v approach infinity, guantity $E$ also becones an infinite series. Furthernore, the bincrial coefficients of infinite indices becone guotients of infinite Frcducts. Thus to investigate the bebavior of $\mathrm{B}_{m \mathrm{~m}}$ as either or both of its indices go to infinity, one vust investigate infinite sues of infinite froducts. a forther ccoflication is the frssicility cf negative terms in Eg. (25a). Ite soluticn ExEressed in Eg. (31) shculd therefcre be investigated romericajly fricr tc inflenentation.

The cnly useful, albeit nob-rigorous, estisate cf the radios cf convergence which the authors have fcund is deternined ty setting all cf the conplerentary error forcticns in eg. (31a) to udity. If the terne cf the series vere non-pegative, this frocedure would frodoce a referedce series fcr use in a confarison test. Cne would tbed bave a Ifgorous froce ce convergence within tbe region of ccnvergence of the reference series.l socb a series 
- ar be suned exactly by sinply reversing the binonial-expansion process used to derelop Egs. (24) and (25) fron Eq- (18) - The radius of convergence for Eg- (23a), vith $y=2 \cdot \overline{D t} / \mathrm{a}$. provides the desired relation:

$$
T=\frac{\partial d}{20}=\frac{a n}{60 s}
$$

where Eq (19) is used to obtain the last expression. 


\section{IPPIICATIOHS}

The gas content of the inner core is of interest. Is stated in section $I$, it is assured that diffusion in the core is instantaneous conpared to diffusion through the shell so the concentration can be taken to be aniforn throughout the core. The boundary conditicns reguice that the pore concentrations on either side of the interface between the core and shell be equal. The gas uptake then is this unifor poce concentration tives the roluce of the inner core tines the porosiry of the inner core. Thos. fron Eg. (16a) vith r=a one obtains the uptake o given by

$$
U=\ddot{U}
$$

where

$$
\begin{gathered}
\because=\frac{4}{3}-a^{2} b c_{0} s \\
\bar{H}=\frac{a}{b}-\sum_{j=0}^{\infty} g\left(x_{j}, 0\right) e^{-D r_{j}^{2} t}
\end{gathered}
$$

and $g(1,0)$ is deterained frov $\mathrm{g} g$. $(16 b)$ with $\rho=0$, and the $x_{j}$ 's are given by Eq. (14b). A conputer progran has been developed to calculate the gas uftake given by Eg. (33). The input parameters reguiced are tbe dinensions a and $b$, the diffusivity $D$, the outside gas concentration $c_{0}$ and the porosities $n$ and s. since $c_{0}$ affeacs only as a nultiplicative factor in $i$. these may be conbined, for the purpose of calculating uptake, into the dimensions a and $t$ and the three paraneters D. q. and $r$ where $q$ is the ratio sa/30 defined by $\mathrm{Eq}$. (3). Pigure 3 1110strates tuo curves representing the uptake as functions of tiue for two different sets of paranetera. The units are arbitrary: the 


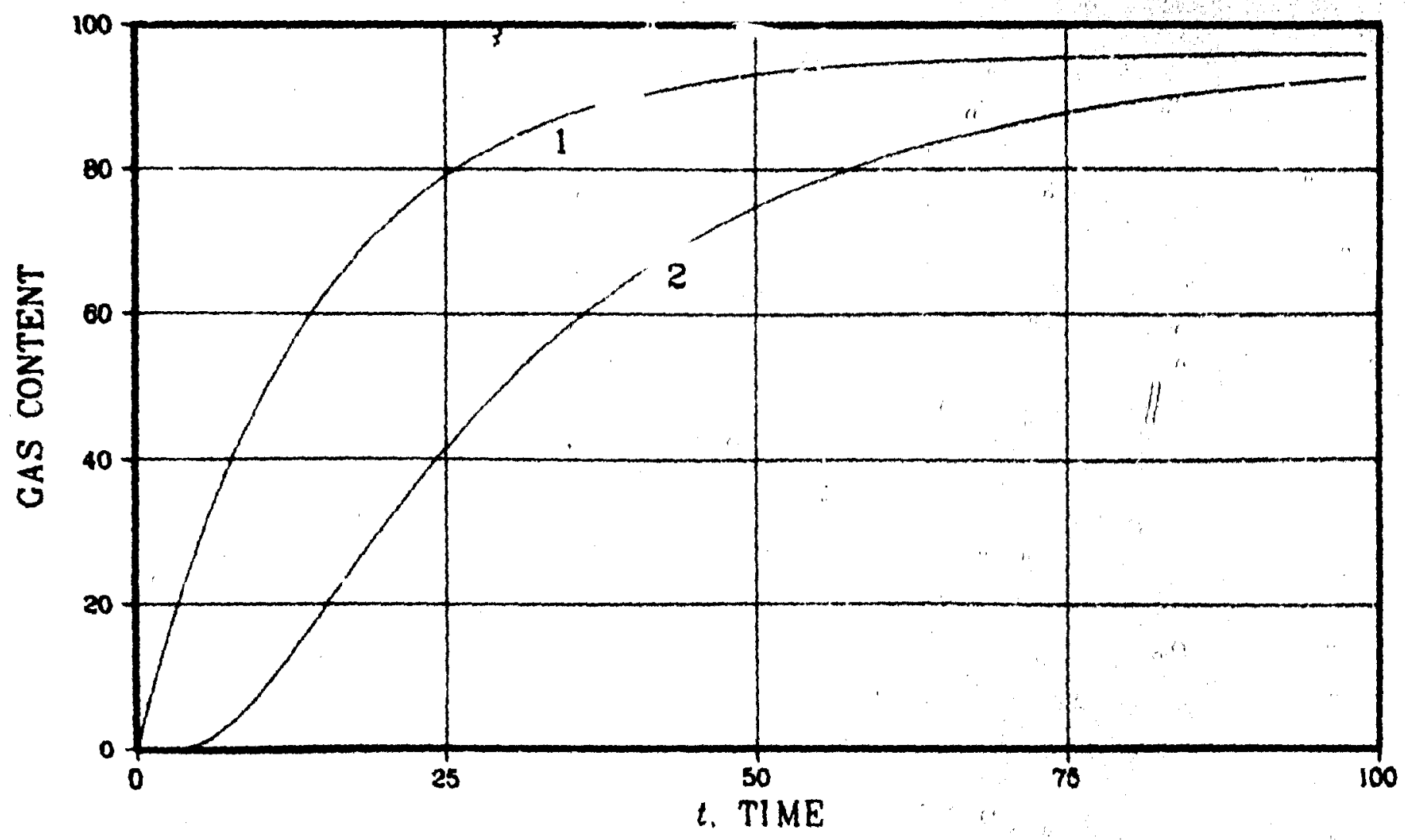

81g. 3. Two sauple cucres showing the bohavior of the theoretical gas ugtake as a tunction of tine for two different sets of parameters. 
dicensicns $a$ and $b$ and paranetér $\gamma$ are the sane for each curve. Corve Ho. 1 has a nch higher diffusivity $D$ and also a larger ralue for the ratio $g$ and would be fit vell by a first-order

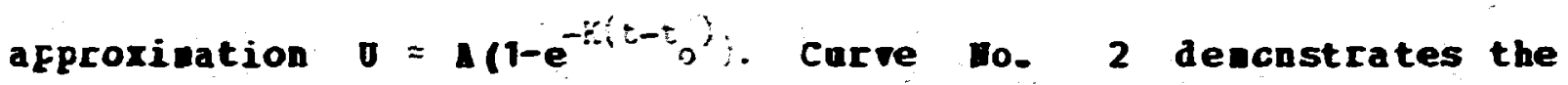
departure fron first order and indicates that the conplete analysis as described in this docunent is necessary for proper treatnent of the problen at siall tines. por exact trentnent at even swaller times, it is necessary to calculate the up ake fron 8gs. (31) of Section IV. but this has not proved necessary to date.

The aptake calculation has been conbined with a data-fitting conputer code to obtain the best fit of the theoretical uptake given by Egs. (33) to experinental neasurenents of the gas aptake by HTGR biso-coated fuel particles. The experimental uptakes are inpot and the best theoretical fit is ade retorning the values of the diffusirity $D$ and the forosities $n$ and $s$. Figure 4 iliustrates the expericental data and the theoretical fit for the helios uptake by fuel particle batch 082261/at at 8500C. A fortbconing report will detail the results of application of this data-fitting procedure to a series of ATGB fuel-particie gas optake measurenents. 


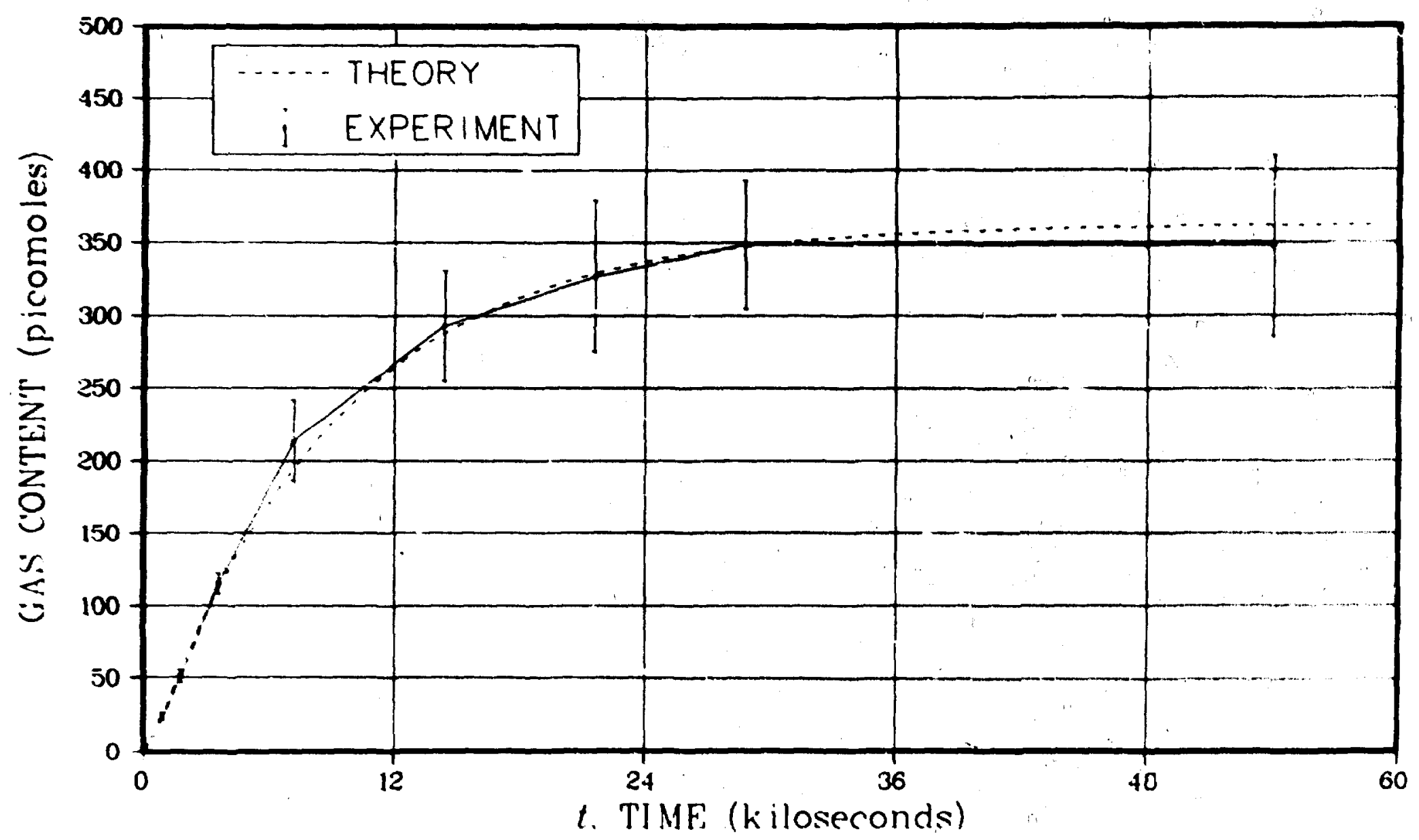

Fig. 4. Experimental data and the theoretical fit for the helium uptake by HTGR fuel-particle batch OR2261/HT at $850^{\circ} \mathrm{C}$. The theoretical iit yields $0=4.055$ $x 10^{-12} \mathrm{~m}^{2} / \mathrm{s}, n=0.0471$, and $s=0.1948$. 


\section{CONCLUSION}

The problen of diffusion through a spherical shell has been solved usiug the laplace transforation technique. Tro Exfressions for the solution have been obtained haring the form of infinite series of special functions. The first expression is affropriate for all ralues of tine wile the second expression provides nore rapid convergence at small tines. Bigorous convergence has been established for all values of time in the former case, and a nonrigorous radias of convergence has been developed in the latter case. Application of the first solution has been ade for the purpose of calculating the gas uptake as a function of time and for the purpose of gbtaining the material parameters $D$, $n$, and $s$ by a data-fitting process. 
$\mathbf{T}$

$t$

0

$\overline{\mathbf{0}}$

I

$\boldsymbol{Y}$

$\mathbf{\alpha}_{\mathbf{j}}$

$B$

$Y$

$c$

$\delta$

$\Gamma$

$\lambda$

$\lambda_{j}$

$\rho$

Badius of convergence of Eg. (31) ... I

rine ... T

Gas uptake of the inaer core. Eq. (33a)

$\ldots$.

Dimensionless optake, Eg- (33c)

Vaciable defined by Eg. (20)

acbitcary variable, $\mathrm{Bg}$. (23)

Paraneters defined by Eg- (14)

Function defined by $\mathrm{Eg}$ - (iB)

Path paraneter for inverse Laplace

transforn of section III ... T-i

optake paraneter of section $v$ defined

by $\mathrm{Eg}$. (33b)

Irbitrary paraneter. Eq. (23)

closed integration contour

Lap lace transfor ation variable ... T-1

Location of $j$-th pole in ccoplex

plane

Radial הistance fron inner surface of shell

$\ldots$ L

Paraveter defined by $\mathrm{Bg}$. (28) ... I 
ORRL/CSD/TM-60

\section{INTERNAL DISTRIBUTION}

1. J. P. Callahan

2. A. J. Caputo

3. H. P. Carter/A. A.CBrooks/ CSD Library

4. H. P. Eathery

5. F. J. Homan

6. H. J. Lackey

7. C.S. Morgan

8. C. W. Nestor, Jr.

9. K. J. Notz

10. S. K. Penriy

11. G. L. Powell
12. R. D. Spence

13. V. J. Tennery

14-23. J.S. Tolliver

24. D. R. Vondy

25. S. K. Whatiey

26-27. Central Research Library

28. Document Reference Section - Y-12

29-31. Laboratory Records

32. Laboratory Records - RC

33. ORNL Patent Office

\section{EXTERNAL DISTRIBUTION}

34. Chief, Mathematics and Geoscience Branch, Department of Energy, Hashington, DC 20545

35. M. Reeves, INTERA Environmental Consultants, Inc., 1201 Dairy Ashford, Suite 200,-Houston, TX - 77079

36. Office of Assistant Manager for Energy Research and Development, DOE/ORO, P. 0. Box E, Dak Ridge, TN 37830

37. J. N. Rogers, Division 8324, Sandia Laboratories, Livermore, CA 94550

38-64. Technical Information Center, Department of Energy, P. 0. Box 62, Oak Ridge, TN 37830 